\title{
IS EMPLOYMENT DECREASING DUE TO MINIMUM WAGE INCREASE?
}

Sanja Blaževića

a Research Assistant, Ph.D, Juraj Dobrila University of Pula, Department of Economics and Tourism "Dr. Mijo Mirković", Preradovićeva 1/1, Pula, Croatia, sanja.blazevic@unipu.hr.

\section{ARTICLE INFO}

Article data:

- Received: 14 September 2012

- Accepted: 21 December 2012

JEL classification: J08, J31, J38, J83

Keywords:

- Minimum Wage

- Employment Rate

- Kaitz index

- Croatia

\section{ABSTRACT}

The paper aims at modelling and quantifying the connection between minimum wage and the employment rate of workers distributed according to age in the Republic of Croatia, on the basis of data from the Labour Force Survey for the period from 2000 to 2010 and by using a panel method with fixed effects aiming at proving the assumed hypothesis on the negative effect of the minimum wage increase on the employment rate of vulnerable groups of workers. The research results indicate the existence of a relationship with a positive direction but little practical significance considering the need for a felt increase of minimum wage.

Reference to this paper should be made as follows: Blažević, S. 2013. Is Employment Decreasing Due to Minimum Wage Increase?, Ekonomska istraživanja - Economic Research 26(1): 69-100. 


\section{INTRODUCTION}

Minimum wage economics has been studied and formed as a separate area of research for more than a century. The social and economic turmoil is changing the minimum wage policy and the scientific efforts put forward contradictory conclusions on its influence. Since "economics was not defined once and for all, rather the topic of interest for the economists, whether in terms of the issues they investigate or the analytical techniques used to deal with these issues, changes and develops in time"1 so does the minimum wage economics keep changing and completing past notions with new notions, depending on the changes that occur.

"The minimum wage is a contentious and emotional issue in the United States and it has been for almost a century"2. According to Levin-Waldman ${ }^{3}$ the cause of so much interest is not efficiency, because the minimum wage is quite low, but rather the belief that the government is imposing a low wage policy. All through history, public opinion has always been different than that of economists while the workers are undoubtedly advocating a minimum wage increase. The opponents of the minimum wage policy think that it is an institutionally obsolete tool that does not fulfil the goal of diminishing the poverty of workers and increasing their purchase power, rather the contrary, it causes a decrease of employment of vulnerable groups on the labour market. The advocates of the minimum wage think that a moderate increase of the minimum wage increases the welfare of low-paid workers as well as their overall negotiating position. The number of advocates of the minimum wage policy has been rapidly growing in the last decade and the majority is rejecting the classical theory focused on the negative effect and defending the empirical evidence provided by Card and $\mathrm{Krueger}^{4}$ with the positive direction. The new literature on minimum wage gained importance in 2006 when 659 economists wrote an open letter ${ }^{5}$ which stated the positive aspects of the minimum wage increase manifested in the elimination of the unbalance in the negotiation on the labour market, the encouragement of monopsonists to increase employment, the coordination of low-paid work market, an increase in productivity and an increased purchase power of the workers.

From the aspect of public policy, the minimum wage is an attractive tool because it does not request an increase of public expenditure while having a strong political symbolism. Although the majority of empirical studies point out the negative effects, the unions have always supported and advocated the minimum wage increase, seen by some economists as an indicator that is "more consistent with economic self-interest than with altruism"6.

The literature on the minimum wage is mainly focused on the role of the minimum wage in the domain of workers' employment while neglecting the social sphere. Looking back, the most frequent research was into the relationship of the minimum wage variables and the employment rates, in particular for certain groups of workers like teenagers and low-wage or less educated workers. The stress was on the employment rate compared to the unemployment rate because

\footnotetext{
1 Željko Mrnjavac, "Povijest ekonomije rada i pogleda ekonomske teorije na nezaposlenost," in Uloga povijesti ekonomske misli u nastavi na fakultetima društvenih znanosti u Hrvatskoj, edited by Đuro Š. Medić and Ivan Ferenčak, Druga znanstvena konferencija katedri za ekonomsku teoriju ekonomskih fakulteta u Hrvatskoj(Osijek; Ekonomski fakultet Osijek, 2001), 18.

${ }^{2}$ Ritchard Sutch, "The unexpected long-run impact of the minimum wage: an educational cascade", NBER Working Paper No. 16355 (2010): 3, http://www.nber.org/papers/w16355.pdf

${ }^{3}$ Oren Levin-Waldman, The case of the minimum wage: competing policy models (New York: State University of New York Press, 2001), 4.

${ }^{4}$ David Card and Alan B. Krueger, Myth and Measurement - The New Economics of the Minimum Wage (New Jersey: Princeton University Press, 1995)

${ }^{5}$ Economists' Statement, "Hundreds of economists say: raise the minimum wage", Economic Policy Institute, (2006): http://www.epi.org/page/-/pdf/epi_minimum_wage_2006.pdf?nocdn=1

${ }^{6}$ David Neumark and William L. Wascher, Minimum wages (United States: The MIT Press, 2008), 284.
} 
due to the minimum wage increase, non active persons might be drawn to the labour market and start actively looking for work, thus becoming part of the workforce that can grow faster than the number of jobs, resulting in an increase of the unemployment rate which is not the result of a decrease of jobs. This makes the unemployment rate an unreliable measure so that the economists have turned to the employment rate instead.

At the beginning of the 20th century there was a scientific debate on the effects of the introduction and increase of the minimum wage and until the 90ies the discussion was based on attempts to prove the assumptions of negative consequences. New literature on the role of the minimum wage widened the discussion in both a positive direction and towards arguments on an overrated effect of the minimum wage. Considering the incoherence of the conclusions trying to quantify the scope of the negative effect on the employment level, a generalized dismissal of the minimum wage policy seems to be too harsh. A total absence or an existence of only a negligible negative effect of the minimum wage on employment can conceal harmful latent consequences in the sense of an intensification of the working hours, which can be very bad for the health and safety of the workers. The influence of the minimum wage on the quantitative and qualitative employment of workers depends on numerous specific factors that need to be taken into consideration when dealing with the minimum wage policy in industry, like the interaction with the general level of wages, the level of education and training, working conditions and the national employment policy?

\section{LITERATURE REVIEW}

The debate surrounding the negative connotations of the effect of the minimum wage on the employment of low-wage workers began at the beginning of the 20th century and precisely in 1906 with evidence provided by Smith and Taussig. A different current of thought was represented by progressive economists (Sidney Webb, Roger Seager and John Commons) who, for social reasons (the problem of workers exploitation), believed the minimum wage to be an indispensable instrument. No consensus has been reached for more than a century so that the issue of the minimum wage is the most frequently used example of theoretical and empirical divergence of opinions among economists. In the last two decades there is a third current of thought that has joined the discussion, one pointing out the argument of an excessive stress on the minimum wage policy which was additionally provoked by Michl ${ }^{8}$ and his statement on the causes of the dissent which are purely of a methodological nature where the opposite results were obtained depending on the use of the dependent variable (ex. number of workers or number of working hours) as well as on the specification of the model.

Since 1980, in the most fertile period of research into the role of the minimum wage, there have been hundreds of studies on the effect and consequences of the minimum wage that differ according to numerous criteria, among which the most important are: a) the source of information, b) the choice of the dependent variable, c) the choice of the time period for research, d) the state that was researched, e) the choice of the group of workers under the influence of the minimum wage, $f$ ) the research of the effect on a micro or macro level, g) the research methodology.

\footnotetext{
${ }^{7}$ Daniel Vaughan Whitehead, "Minimum wage revival in the enlarged EU: explanatory factors and developments," in The minimum wage revisited in the enlarged EU, edited by Daniel Vaughan Whitehead (International Labour Organization: Edward Elgar Publishing Limited, 2010), 33.

${ }^{8}$ T.R. Michl, "Can rescheduling explain the New Jersey minimum wage studies?", Eastern Economic Review, 26, no. 3 (2000): 265-276.
} 
The most frequently used source of information for the analysis of the effect of the minimum wage is the workforce research or the Labour Force Survey (LFS) in Croatia. The greatest number of researches regards the USA where scientists mostly use the Current Population Survey (CPS) as the most detailed research of the working population. The problems arising from such sources are auto-selection, validity, verifiability, reliability, etc. However, from the point of view of methodology, greater problems arise in surveys conducted independently by the scientists, namely the problem of sampling, the way the survey is conducted, repeated questioning and similar. These are all arguments against the research conducted by Card and Krueger who proved the positive effect of the minimum wage on employment through a telephone survey of selected units so that the reliability of their sample is often put in question. The LFS is conducted in most countries so it is possible to compare results and, regardless of some methodological doubts, it remains the most representative source for this kind of research.

The effect of the minimum wage on employment usually takes the employment rate as a dependent variable. Although most research finds a negative relation between the minimum wage and employment, the existence of doubt started a wave of research using working hours as the dependent variable. Authors promoting conclusions on the negative relation of the minimum wage and employment confute the opposing research with the argument of increased working hours, which proves the negative connotation of the minimum wage for the vulnerable groups of workers on the labour market. However, there is much debate around this issue as well because of contradictory evidence. Bernstein and Schmitt ${ }^{9}$ pointed to the fact that companies can choose to reduce the working hours of existing employees instead of reducing the number of workers, which makes sense in terms of the traditional model lead by the costs of work. According to their interpretation, companies shall look for ways to reduce the use of a more expensive input, so if they keep the existing level of employment, they will reduce the number of working hours which will result in a decrease of wages. Some recent research ${ }^{10}$ indicates that there is no connection between the minimum wage and working hours. Danziger ${ }^{11}$ found the cause for diverse conclusions on the effect of the minimum wage on working hours in the non-observance of the Labour Act and the likelihood for the employer to be fined for non-observance (employer's risk), which affects job offer.

The time period is relative to a) the time series taken for the research, b) the effect of the minimum wage in the short, medium and long run. The analyses show that the use of the same methodological framework on the same variables but for a different period leads to different conclusions ${ }^{12}$. As for the horizons of the observed effects of the minimum wage, Baker, Benjamin and Stanger ${ }^{13}$ concluded that employment adapts in the long run due to current and past changes of the minimum wage by which the dynamic response of employment to the minimum wage changes cannot be optimally described with short-term parameters but with those having a

\footnotetext{
${ }^{9}$ Bernstein, Jared and John Schmitt. "Making work pay. The impact of the 1996-97 minimum wage increase," Economic Policy Institute, Washington (1998): 37, http://www.epi.org/publication/studies_stmwp/

${ }^{10}$ Dale L. Belman and Paul Wolfson. "The effect of legislated minimum wage increase on employment and hours: a dynamic analysis", Labour, 24, no. 1 (2010): 1-25.

${ }^{11}$ Danziger, Leif. "Noncompliance and the effects of the minimum wage on hours and welfare in competitive labor markets," IZA Working Paper No. 4408 (2009), papers.ssrn.com/sol3/Delivery.cfm/dp4408.pdf?abstractid=1489231 \&mirid $=1$

${ }^{12}$ Nicolas Williams and Jeffrey A. Mills, J.A. "The minimum wage and teenage employment: evidence from time series", Applied Economics, 33, no. 3 (2001): 285-300.; Stephen Bazen and Velayoudom Marimoutou. "Looking for a needle in a haystack? A re- examination of the time series relationship between teenage employment and minimum wages in the United States", Oxford Bulletin of Economics and Statistics, vol. 64 (December 2002): 699-725.

${ }^{13}$ Michael Baker, Benjamin, Dwayne and Shuchita Stanger. "The highs and lows of the minimum wage effect: a time series cross-section study of the Canadian law", Journal of Labor Economics, vol. 17, no. 2 (1999): 318-350.
} 
longer planning horizon (like input substitution). Belman and Wolfson ${ }^{14}$ proved that changes and adjustments of employment take place within two and a half years, while adjustments in the working hours take place after the first year, meaning that the horizon included in the research should be carefully determined to avoid making erroneous conclusions on the (non) existence of connection due to the short-term character of the analysis.

Considering the geographical determinant, research can be divided in three groups of states: developed, developing and undeveloped. The level of development is relative to economic indicators, in particular of the labour market (the level on (un)employment, the level of labour market flexibility, participation of young workers, level of union organization, volume of unofficial economy, presence and role of labour market institutions and similar). So many studies research developed countries that Alatas and Cameron find it "surprising that there are so few papers on this topic in developing countries, given that minimum wages are also widely employed there as a means of raising living standards. The issue of minimum wage setting in low-wage countries has stimulated considerable international interest, with concerned citizens in wealthy nations calling for higher wages to be paid in developing countries to limit the exploitation of labour by multinational corporations"15. The characteristics of economy and labour market may influence the differences in conclusions on the role of the minimum wage so that it is necessary to gather as much information as possible on the characteristics of the selected states and the included variables as well as the used methodology in order to discover a possible pattern in drawing conclusions considering the research process design. For example, Neumark and Wascher ${ }^{16}$ came to the conclusion that the minimum wage does not result in a decreased employment in those countries in which it is determined by way of national collective negotiating. Also, according to their research, in more rigid labour markets minimum wage has a stronger negative effect as well as in those with a higher level of union organization.

Teenagers (persons from 15 to 19 years of age) are a group of workers that are traditionally analyzed when speaking of the minimum wage impact. The most popular model that was taken as a consensus for a whole decade (in the 80ies) is the BGK model ${ }^{17}$. With this model the authors started research that tried to prove or refute their conclusion that a minimum wage increase by $10 \%$ decreases the employment of young workers between $1 \%$ and $3 \%$. According to the frequency of research, the groups of workers on whom the minimum wage can have various effects are the younger workers (from 20 to 24 years of age), low-wage workers, women, migrants and older workers.

The macro level of the minimum wage effect within the analysis of employment includes the dependent variable of the aggregate employment rate while the micro level of the research relates to the analysis of the impact on single groups of workers considering the demographic, economic and social characteristics like sex, age, education, location in the wage distribution, the actual job of the worker, residence (urban or rural area).

The cause of such variegated research conclusions can be of a methodological nature, mainly due to the use of various proxy minimum wage variables ${ }^{18}$ or different theoretical (perfect

\footnotetext{
${ }^{14}$ Dale L. Belman and Paul Wolfson. "The effect of legislated minimum wage increase on employment and hours: a dynamic analysis", Labour, 24, no. 1 (2010): 1-25.

${ }^{15}$ Vivi Alatas Lisa A. Cameron. "The impact of minimum wages on employment in a low-income country: a quasi-natural experiment in Indonesia," Industrial and Labor Review, vol. 61, no. 2, article 4 (2008), 201.

${ }^{16}$ David Neumark and William L. Wascher, Minimum wages (United States: The MIT Press, 2008), 90-91.

${ }_{17}$ Charles Brown, Gilroy, Curtis and Andrew Kohen. "The effect of the minimum wage on employment and unemployment," Journal of Economic Literature, vol. 20, no. 2 (1982): 487-528.

${ }^{18}$ Sara Lemos. "How do alternative minimum wage variables compare?" Working Paper No 05/6, University of Leicester, Department of Economics, 2005, https://Ira.le.ac.uk/bitstream/2381/4438/1/dp05-6.pdf
} 
competition model, monopsony model, political model) and empirical models (difference-indifferences method, time series analysis, panel analysis).

\section{METHODOLOGY OF RESEARCH INTO THE CONNECTION BETWEEN MINIMUM WAGE AND EMPLOYMENT RATE}

The data used in the research are unprocessed entries of answers provided by the respondents in the Labour Force Survey (LFS) conducted by the Croatian Bureau of Statistics and they encompass the period from 2000 to 2010 on a semi-annual basis. Considering the fact that the LFS has been conducted on a quarterly basis since 2007, wanting to keep the dynamics of processing for the semi-annual data, the answers for the first and third trimester as well as the answers for the second and fourth semester from 2007 to 2010 have been summed. The dynamics of surveying (2-2-2) is such that households are surveyed in two consecutive trimesters, left out of the sample for the next two and surveyed again in the following two consecutive trimesters. By joining trimesters we avoid the repetition of the same households in the sample. On average, around 5,600 residential units are selected into the sample in one trimester.

Although the LFS and its variants are used in most minimum wage research, there are methodological problems that can arise from the use of this seemingly most reliable source of information. "The drawbacks of this kind of information gathering can be technical and statistical problems of the scope of the representative sample, changes in the size and composition of the sample, credibility of the answers, and precision of estimates based on the sample and the interpretation of changes during different periods of time"19. The LFS is conducted by surveying the population which makes the answers not entirely reliable, regardless of the anonymity of the survey. Another potential problem is the registration of the answers by the person conducting the survey as well as the statistician turning the answers into codes. When a mistake is spotted when entering the data it is difficult to double check the answer, all the more with the passing of time. The person conducting the survey may repeat the question right away but the statistician cannot do that when entering the data. Several solutions are possible: mark the mistake as a missing value or enter the most likely answer for that person. The next problem is the problem of self-selection. For example, when addressing the issue of minimum wage, the obtained results indicate that it has the greatest negative effect on teenage employment rate but teenagers can also be the least productive or the least motivated workers (because they are still in school or know they can rely on the family income) that may be laid off first in case of a minimum wage increase and substituted for more productive workers. The social expenditure would not be substantial in that case and the conclusion may go in the negative direction for teenagers.

The research includes 22 time periods $(t)$. The persons included in the sample are those that answered the question on the amount of their net wage while the peak values have been eliminated. The sample includes dependent workers and craftsmen, meaning those self-employed workers and those not under a work contract are excluded from the sample. In the LFS this question is relative to the position in employment which includes all those respondents working in state enterprises, institutions, organizations, working for an employer in the private sector, working in an enterprise undergoing the transition process and those that work or are entrepreneurs in their own craft. The sample did not include workers/entrepreneurs in their own enterprise, farmers, freelance workers/entrepreneurs, aiding members, those employed with an authoring contract, service contract, student's contract and similar contracts as well as those paid directly in cash, nature or by agreement. The sample was also restricted to those workers working

\footnotetext{
${ }^{19}$ Željko Mrnjavac. Mjerenje nezaposlenosti (Split: Ekonomski fakultet Split, 1996), 40.
} 
for more than 30 hours a week. This made the structure of the respondents similar to that considered by the Croatian Bureau of Statistics when calculating the average wage in Croatia.

\section{TABLE 1 - DATA ON THE NUMBER AND WAGES OF RESPONDENTS IN THE LFS FROM 2000 TO 2010}

\begin{tabular}{|c|c|c|c|}
\hline Period & Number of respondents & $\begin{array}{l}\text { Share of answers on net } \\
\text { wage (\%) }\end{array}$ & $\begin{array}{l}\text { Net wage interval of } \\
\text { the sample }\end{array}$ \\
\hline $2000: 1$ & 20,503 & 31.61 & $0.1-32,000$ \\
\hline $2000: 2$ & 18,214 & 34.85 & $0,1-31,500$ \\
\hline $2001: 1$ & 20,044 & 34.71 & $0,1-30,000$ \\
\hline $2001: 2$ & 18,944 & 35.12 & $0,1-40,000$ \\
\hline 2002:1 & 22,592 & 35.51 & $0,1-20,000$ \\
\hline $2002: 2$ & 21,465 & 35.88 & $0,1-33,600$ \\
\hline 2003:1 & 20,402 & 36.17 & $0,1-40,000$ \\
\hline 2003:2 & 19,624 & 36.22 & $0,1-45,000$ \\
\hline 2004:1 & 19,255 & 37.33 & $0,1-40,000$ \\
\hline 2004:2 & 18,751 & 36.41 & $0,1-36,000$ \\
\hline 2005:1 & 18,723 & 34.97 & $0,1-28,000$ \\
\hline $2005: 2$ & 18,226 & 35.53 & $0,1-30,000$ \\
\hline 2006:1 & 18,077 & 34.58 & $0,1-30,000$ \\
\hline 2006:2 & 17,538 & 36.45 & $0,1-30,000$ \\
\hline 2007:1 & 22,712 & 38.02 & $0,1-33,000$ \\
\hline 2007:2 & 22,606 & 38.22 & $0,1-33,000$ \\
\hline 2008:1 & 22,095 & 38.71 & $0,1-33,000$ \\
\hline $2008: 2$ & 21,813 & 38.82 & $0,1-40,000$ \\
\hline 2009:1 & 21,140 & 38.09 & $0,1-30,000$ \\
\hline 2009:2 & 21,155 & 37.92 & $0,1-30,000$ \\
\hline 2010:1 & 20,076 & 30.23 & $0,1-25,000$ \\
\hline 2010:2 & 19,996 & 36.06 & $0,1-35,000$ \\
\hline
\end{tabular}

Source: Author's calculation based on the LFS entries.

The model was elaborated on an individual level in two variants considering the use of various minimum wage variables. In his work in 1999, Brown pondered the role of data handling and specification in reaching conclusions. He concluded that researchers should use various specifications to test the robustness of the model and include as many control variables as possible $^{20}$.

${ }^{20}$ See: Olalekan Edagbami. "The employment effects of the minimum wage: a review of the literature," Research Report W/32, Work Network, Canadian Policy Research Networks (2006), 19: http://hussonet.free.fr/edagbami.pdf 
The research was conducted using a panel analysis aiming to prove the assumed negative relation between the minimum wage and the employment rate of workers distributed according to age. A panel analysis was used which set some limitations in modelling. First, it is hard to separate the exclusive effect of the minimum wage because other factors can influence movements on the labour market, like economic cycles, trade conditions, exchange rate, technological conditions and similar. Another problem is the complex econometric methodology that is still developing (the problem of stationarity, endogeneity, seasonal variations, structural breaks, insufficient dispersion of data through time which is also visible in issues such as the minimum wage and model specification).

\section{THE EFFECT OF THE MINIMUM WAGE ON EMPLOYMENT RATE - RESEARCH}

The interdependence of the minimum wage and the employment rate is analyzed in more detail in various age groups of workers following the conclusions from literature ${ }^{21}$ according to which some age groups of workers, like teenagers, are more affected by the minimum wage increase which manifests itself in a decrease of their employment rate. Since on the Croatian labour market, considering age, people in higher age groups are also part of the vulnerable group of workers, the data on workers were extracted for the following groups of workers:

- $\quad$ group $1=$ workers from 15 to $19 \quad(i=1)$

- $\operatorname{group} 2=$ workers from 20 to $24 \quad(i=2)$

- $\quad$ group $3=$ workers from 25 to $29 \quad(i=3)$

- group $4=$ workers from 30 to $39 \quad(i=4)$

- $\quad$ group $5=$ workers from 40 to $49 \quad(i=5)$

- $\operatorname{group} 6=$ workers from 50 to $59 \quad(\mathrm{i}=6)$

- $\quad$ group $7=$ workers from 60 to $65 \quad(i=7)$

The age groups of workers (i) set for the period from 2000 to 2010 represent a quasi/pseudo pane ${ }^{22}$ (hereinafter: panel) structure of data which makes the specification of the model as follows:

$$
\text { rate_emp } p_{i t}=\beta_{0}+\beta_{1} M W_{t}+\beta_{2} \text { rate }_{e} e m p_{i t-1}+\beta_{3} \bar{X}_{i t}+\beta_{4} Z_{t}+u_{t}
$$

where the dependent variable stands for the rate of employment for the group of workers $i$ in the period $t$, i.e. the previous period $(t-1)$. The variable $M W$ stands for the minimum wage variable, $\bar{X}$ stands for the control variables vector, while $Z$ stands for the dummy variable of the coming into effect of the Minimum Wage Act.

The source of the calculation of independent variables of single groups of workers is the LFS. Since the LFS is not a longitudinal panel and it is therefore not possible to spot changes on

${ }^{21}$ Charles Brown, Gilroy, Curtis and Andrew Kohen. "The effect of the minimum wage on employment and unemployment," Journal of Economic Literature, vol. 20, no. 2 (1982): 487-528.; David Card and Alan B. Krueger, Myth and Measurement - The New Economics of the Minimum Wage (New Jersey: Princeton University Press, 1995)

${ }^{22}$ The quasi or pseudo panel structure of data marks a grouped sample from the LFS where each period includes some other individuals in the group 
the individual level for each worker, the respondents were grouped as above in order to spot the differences between them. The employment rate for the whole sample is calculated so that respondents older than 15 are selected to obtain the size of the working population while the number of employed people is obtained by isolating people over 15 who were at work or performing the activity they make a living from the previous week (at least for an hour) or did not do that but have a job to go back to or those people who are aiding members who, in the previous week (for at least an hour), worked for a compensation in money, nature or for the wellbeing of the family. The employment rate according to age groups was calculated by using the same methodology applied by the Croatian Bureau of Statistics, where the size of the working population was relative to the number of respondents in the observed age group while the number of employed people in this age group was obtained by isolating only the employed. The obtained employment rates match the officially published employment rates in the yearbook of the Croatian Bureau of Statistics but since the CBS does not calculate the employment rate of a larger number of age groups of workers, such as were needed for this research, the employment rates were calculated by using the LFS. 
TABLE 2 - DESCRIPTION OF VARIABLES OF THE PANEL MODEL (ANALYSIS - AGE STRUCTURE OF WORKERS)

\begin{tabular}{|c|c|c|}
\hline Mark & Description & Source \\
\hline \multirow[t]{3}{*}{$\overline{\mathrm{MW}}$} & "Minimum wage variables: & \\
\hline & - nominal minimum net wage & $\mathrm{CBS}^{23}$ \\
\hline & - Kaitz index & Independent calculation ${ }^{24}$ \\
\hline Rate_emp $\mathrm{t}_{\mathrm{t}-1}$ & $\begin{array}{l}\text { Lagged employment rate } \\
\text { (employment rate in the previous } \\
\text { period) }\end{array}$ & CBS \\
\hline \multirow{8}{*}{$\bar{X}$} & Control variables vector including: & \\
\hline & $\begin{array}{l}\text { - share of highly educated people in } \\
\text { the total number of workers }\end{array}$ & LFS \\
\hline & $\begin{array}{l}\text { - share of women in the total } \\
\text { number of workers }\end{array}$ & LFS \\
\hline & $\begin{array}{l}\text { - share of urban population in the } \\
\text { total number of workers }\end{array}$ & LFS \\
\hline & - average work experience & LFS \\
\hline & & Croatian Central Bank \\
\hline & - minimum wage coverage & LFS \\
\hline & - nominal average net wage & CBS \\
\hline \multirow[t]{3}{*}{ Z } & $\begin{array}{l}\text { Binary variable of the following } \\
\text { values: }\end{array}$ & \\
\hline & $\begin{array}{l}0=\text { Minimum Wage Act not in force } \\
\text { (until the second semester 2008) }\end{array}$ & \\
\hline & $\begin{array}{l}\text { 1=Minimum Wage Act in force } \\
\text { (from the second semester 2008) }\end{array}$ & \\
\hline
\end{tabular}

Source: Author's calculation.

In the panel analysis, the minimum wage variables include the nominal net wage (in log form) and the Kaitz index which uses the average wage for the single group of workers resulting in the Kaitz index for the observed group.

It is necessary to test the stationarity of the variables before the modelling, as shown in table 3. Considering the relatively small sample of time observations (22) and the section units (seven groups of workers) but also a balanced panel, a Levin-Li-Chu (LLC) test was used assuming joint processes of all observed sections in which the nul hypothesis is the existence of $I(0)$, i.e. stationary processes. The results are elaborated further with the use of the Im-Pesaran-Shin (IPS) test in which the nul hypothesis is the stationarity of all series/sections in the panel while the alternative hypothesis is that there are non stationary processes in some sections.

\footnotetext{
${ }^{23}$ Minimum net wage $=$ minimum gross wage $-20 \%$

${ }^{24}$ Ratio of minimum and average wage (for single groups of workers) 
TABLE 3 - STATISTICAL SIGNIFICANCE (P VALUES) OF LLC AND IPS STATISTICS (UNIT ROOT TESTING)

\begin{tabular}{|c|c|c|c|c|c|c|}
\hline \multirow{2}{*}{ Variable } & \multicolumn{2}{|c|}{ Constant } & \multicolumn{2}{|c|}{ Constant and trend } & \multicolumn{2}{|c|}{ First difference } \\
\hline & LLC & IPS & LLC & IPS & LLC & IPS \\
\hline Employment rate* & 0.0074 & 0.0681 & 0.0073 & 0.0246 & 0.0000 & 0.0000 \\
\hline $\begin{array}{l}\text { Log of minimum net } \\
\text { wage** }^{*}\end{array}$ & 0.9533 & 1.0000 & 0.0538 & 0.0305 & 0.0000 & 0.0000 \\
\hline $\begin{array}{l}\text { Kaitz index } \\
\text { (average wage)** }\end{array}$ & 0.9150 & 0.9754 & 0.0048 & 0.0739 & 0.0000 & 0.0000 \\
\hline $\begin{array}{l}\text { Log of average net } \\
\text { wage* }^{*}\end{array}$ & 0.0000 & 0.0014 & 0.0001 & 0.0446 & 0.0000 & 0.0000 \\
\hline $\begin{array}{l}\text { Share of highly } \\
\text { educated* }\end{array}$ & 0.0002 & 0.0006 & 0.0000 & 0.0000 & 0.0000 & 0.0000 \\
\hline Share of women* & 0.0000 & 0.0001 & 0.0000 & 0.0000 & 0.0000 & 0.0000 \\
\hline $\begin{array}{l}\text { Share of urban } \\
\text { population* }\end{array}$ & 0.0140 & 0.0191 & 0.0003 & 0.0000 & 0.0000 & 0.0000 \\
\hline Experience* & 0.0000 & 0.0000 & 0.0000 & 0.0000 & 0.0000 & 0.0000 \\
\hline $\begin{array}{l}\text { Lagged GDP growth } \\
\text { rate }^{* *}\end{array}$ & 1.0000 & 0.6542 & 1.0000 & 0.9874 & 0.0000 & 0.0000 \\
\hline $\begin{array}{l}\text { Minimum wage } \\
\text { coverage* }^{*}\end{array}$ & 0.0000 & 0.0000 & 0.0000 & 0.0000 & 0.0000 & 0.0000 \\
\hline
\end{tabular}

Source: Research results

Legend: ${ }^{*}$ stationary variable ${ }^{* *}$ nonstationary variable

Separate testing was performed for the existence of unit characteristic values of variables per sections in order to determine the correct specification of the model when analyzing the effect of the minimum wage variables on the employment rate of single groups of workers. 
TABLE 4 -STATISTICAL SIGNIFICANCE (P VALUES) OF IPS STATISTICS (UNIT ROOT TESTING)

\begin{tabular}{|c|c|c|c|c|c|c|c|}
\hline \multirow{2}{*}{ Variable 58} & \multicolumn{7}{|c|}{ IPS } \\
\hline & 1 & 2 & 3 & 4 & 5 & 6 & 7 \\
\hline Employment rate & 0.4546 & 0.0665 & 0.2867 & 0.2211 & 0.1682 & 0.1469 & 0.7919 \\
\hline Kaitz index (average wage) & 0.3031 & 0.8479 & 0.4333 & 0.9685 & 0.9533 & 0.8639 & 0.6773 \\
\hline Log of average net wage & 0.8497 & 0.0100 & 0.6231 & 0.0174 & 0.0115 & 0.3162 & 0.0517 \\
\hline Share of highly educated & - & 0.0064 & 0.9680 & 0.0080 & 0.0057 & 0.6373 & 0.0188 \\
\hline Share of women & 0.6258 & 0.3328 & 0.0005 & 0.0083 & 0.0014 & 0.4756 & 0.4306 \\
\hline Share of urban population & 0.0399 & 0.9544 & 0.1617 & 0.3117 & 0.5820 & 0.5375 & 0.0002 \\
\hline Experience & 0.0245 & 0.0000 & - & 0.1143 & 0.0002 & 0.4322 & 0.0891 \\
\hline Minimum wage coverage & 0.0000 & 0.0410 & 0.0441 & 0.0603 & 0.0506 & 0.0282 & 0.0008 \\
\hline
\end{tabular}

Source: Research results

Legend: group 1 - workers from 15 to 19 years of age group 2 - workers from 20 to 24 years of age group 3 - workers from 25 to 29 years of age group 4 - workers from 30 to 39 years of age group 5 - workers from 40 to 49 years of age group 6 - workers from 50 to 59 years of age group 7 - workers from 60 to 64 years of age

The following table shows the results of the effects of the minimum wage variables on the employment rate with the use of OLS model with fixed effects and differentiated non-stationary variables.

TABLE 5 - EFFECT OF MINIMUM WAGE VARIABLES ON EMPLOYMENT RATE (PANEL ANALYSIS - AGE STRUCTURE)

\begin{tabular}{ll}
\hline \hline Minimum wage variable & Panel OLS \\
& (fixed effects, differentiated nonstationary variables) \\
\hline \hline Log of minimum net wage & 7.57 \\
& $(3.27)^{* *}$ \\
Kaitz index (average wage) & 0.005 \\
& $(0.06)$ \\
\hline \hline
\end{tabular}

Source: Research results

The table shows the coefficients of effects and standard error (in brackets)

Legend: ${ }^{* *}$ statistically significant at a level of significance of $5 \%$

Fixed and random effects models are methods used to estimate undetected effects between sections or in time. The fixed effect uses transformations to remove the undetected effects due to correlation while the random effect is attractive in case the undetected effect is not correlated to the other independent variables in the model. A fixed effects model was used since the intention of the research was to allow heterogeneity between section units or groups of workers, whereby it cannot be stated with certainty that the undetected effect is not correlated with other independent variables. The OLS model with fixed effects and differentiated non-stationary 
variables points out a positive relationship whereby a minimum wage increase by $1 \%$ influences an increase of the employment rate by 0,7 , which has no significant practical importance because this is a substantial increase of the minimum wage.

The analysis was elaborated further for each single group of workers depending on their age, in order to analyze the effect on a certain age group and in keeping with the postulates of the first auxiliary hypothesis, a negative relationship is expected for teenagers, young and older workers. The OLS method with fixed effects on differentiated variables was used.

TABLE 6 - EFFECT OF MINIMUM WAGE VARIABLES ON THE EMPLOYMENT RATE OF SINGLE GROUP OF WORKERS ${ }^{25}\left(\mathrm{HAC}^{26}\right)$

\begin{tabular}{llllllll}
\hline \hline Minimum wage variables & 1 & 2 & 3 & 4 & 5 & 6 & 7 \\
\hline \hline Log of minimum net wage & 12.02 & 21.23 & 34.40 & 13.48 & 5.45 & 3.46 & 27.30 \\
& $(10.27)$ & $(33.47)$ & $(21.59)$ & $(12.30)$ & $(9.22)$ & $(8.54)$ & $(11.64)$ \\
\multirow{2}{*}{ Kaitz index (average wage) } & 0.15 & 0.19 & 0.71 & -0.15 & 0.28 & 0.07 & 0.04 \\
& $(0.15)$ & $(0.49)$ & $(0.39)^{* * *}$ & $(0.25)$ & $(0.26)$ & $(0.19)$ & $(0.20)$ \\
\hline \hline
\end{tabular}

Source: Research results

The table shows the coefficients of effects and standard error (in brackets)

Legend: ${ }^{* *}$ statistically significant at a level of significance of $5 \%$

***statistically significant at a level of significance of $10 \%$

The OLS analysis of joined data does not indicate the existence of a negative relationship between the minimum wage variables and the employment rates for any of the age groups of workers. The results are the following:

- The increase of the difference of the Kaitz index obtained with the average wage for one unit influences the increase of the difference in the employment rate of young workers from 25 to 29 years of age by 0.71 at a level of significance of $10 \%$.

- In the group of workers aged 60 to 65 , the increase of the difference in logarithms of the nominal minimum net wage by 0.1 increases the difference in the employment rate by 2.7 at a level of significance of $5 \%$. The average change of the difference of the log minimum gross wage is 0.02 and the maximum is 0.12 , meaning that there is a probability of change by 0.1 that, in practice, can lead to considerable changes in employment for single groups of workers categorized by age, however, this would be an exceptional increase of the minimum wage.

- There is no evidence of a statistically significant relationship between any of the minimum wage variables and the employment rate of teenagers, young workers aged 20 to 24 , workers aged 30 to 39 and workers aged 40 to 49 and 50 to 59 years of age.

The analysis of joint data did not find evidence confirming part of the hypothesis relative to the existence of a negative relationship between the minimum wage increase and the

\footnotetext{
${ }^{25}$ Group 1 - workers from 15 to 19 years of age; group 2 - workers from 20 to 24 years of age; group 3 - workers from 25 to 29 years of age; group 4 - workers from 30 to 39 years of age; group 5 - workers from 40 to 49 years of age; group 6 workers from 50 to 59 years of age; group 7 - workers from 60 to 64 years of age

${ }^{26} \mathrm{HAC}$ stands for Newey-West HAC method which assumes the uncorrelatedness of residuals. It is an estimate that is consistent in cases of heteroskedasticity and autocorrelation of an unknown form.
} 
employment rate of teenagers, young and older workers, which is in keeping with the data obtained with the OLS panel analysis with fixed effects indicating a statistically positive relationship if we observe the whole group of workers divided by age, although the practical significance is minimal. In the context of the set hypotheses, it can be concluded that the negative impact of the minimum wage variables on the employment rate of teenagers, young workers and older workers was not proved.

\section{CONCLUSION}

The minimum wage policy is largely based on strong psychological and political motives. "We need to summarize all the conclusions from a wide range of literature in order to be able to give guidelines to the public policy holders, however, it is quite difficult due to the large number of researches as well as the real complexity of the matter"27. The grouping of workers according to age characteristics indicates a direct positive relationship between the minimum wage variables and the employment rate whereby the minimum wage increase by $1 \%$ results in an increase of the employment rate by 0.7 , which has no particular practical importance, regardless of the fact that the magnitude of the effect is significant, because this is a substantial increase of the minimum wage. The analysis of joint data did not show the existence of a negative relationship between the minimum wage variables and the employment rate of teenagers meaning that the negative effect was not proved. The assumed negative effect of the minimum wage increase on the employment rate of younger workers is refuted by the research results which indicate that an increase of the Kaitz index obtained from the average wage (meaning that the Kaitz index is declining) by one point affects the increase of the difference in the employment rate of young workers from 25 to 29 years of age by 0.71 at a level of significance of $10 \%$. Namely, in the context of a minimum wage increase, this would mean that the average wage remains unchanged or that it changes to a lesser extent than the minimum wage, which has a positive effect on the employment rate of young workers. In the group of workers from 60 to 65 years of age there is a positive effect of the minimum wage increase on the employment rate, which refutes the set hypothesis on the negative effect.

Although positive effects of the minimum wage increase are noted in some groups of workers with an unfavourable position on the labour market, these are practically imperceptible values. There is room for future research in the analysis of single groups of workers with a more complex methodology "as well as a long-term horizon for labour force adjustment in response to a change in the minimum wage, and with a view to incorporating vital evolutionary changes and dynamics in the labour market" ${ }^{12}$. Also, it would be a good idea to introduce a longitudinal study of a representative sample of workers in the Republic of Croatia in order to clearly see the changes in the life and working cycle of workers as well as the interdependence of single variables, which would certainly lead to a better understanding of the functioning of the labour market and to the creation of effective public policy measures.

\footnotetext{
${ }^{27}$ See: David Neumark and William L. Wascher, Minimum wages (United States: The MIT Press, 2008), 287.

${ }^{28}$ Olalekan Edagbami. "The employment effects of the minimum wage: a review of the literature," Research Report W/32, Work Network, Canadian Policy Research Networks (2006), 35: http://hussonet.free.fr/edagbami.pdf
} 


\section{REFERENCES}

Alatas, Vivi and Lisa A. Cameron."The impact of minimum wages on employment in a lowincome country: a quasi-natural experiment in Indonesia,"Industrial and Labor Review, vol. 61, no. 2, article 4 (2008), 201-223.

Baker, Michael, Benjamin, Dwayne and Shuchita Stanger. "The highs and lows of the minimum wage effect: a time series cross-section study of the Canadian law," Journal of Labor Economics, vol. 17, no. 2 (1999): 318-350.

Bazen, Stephen and Velayoudom Marimoutou. "Looking for a needle in a haystack? A reexamination of the time series relationship between teenage employment and minimum wages in the United States," Oxford Bulletin of Economics and Statistics, vol. 64 (December 2002): 699-725.

Belman, Dale L. and Paul Wolfson. "The effect of legislated minimum wage increase on employment and hours: a dynamic analysis", Labour, 24, no. 1 (2010): 1-25.

Bernstein, Jared and John Schmitt. "Making work pay. The impact of the 1996-97 minimum wage increase," Economic Policy Institute, Washington (1998), http://www.epi.org/publication/studies_stmwp/

Brown, Charles, Gilroy, Curtis and Andrew Kohen. "The effect of the minimum wage on employment and unemployment,"Journal of Economic Literature, vol. 20, no. 2 (1982): 487528.

Card, David and Alan B. Krueger.Myth and Measurement - The New Economics of the Minimum Wage.New Jersey: Princeton University Press, 1995.

Danziger, Leif. "Noncompliance and the effects of the minimum wage on hours and welfare in competitive labor markets," IZA Working Paper No. 4408 (2009), papers.ssrn.com/sol3/Delivery.cfm/dp4408.pdf?abstractid=1489231\&mirid=1

Economists' Statement, "Hundreds of economists say: raise the minimum wage", Economic Policy Institute,(2006):

http://www.epi.org/page/pdf/epi_minimum_wage_2006.pdf?nocdn=1

Edagbami, Olalekan. "The employment effects of the minimum wage: a review of the literature,"Research Report W/32, Work Network, Canadian Policy Research Networks (2006), http://hussonet.free.fr/edagbami.pdf

Lemos, Sara. "How do alternative minimum wage variables compare?"Working Paper No 05/6, University of Leicester, Department of Economics, 2005, https://lra.le.ac.uk/ bitstream/ /2381/4438/1/dp05-6.pdf

Levin-Waldman, Oren.The case of the minimum wage: competing policy models. New York: State University of New York Press, 2001.

Michl, T.R. "Can rescheduling explain the New Jersey minimum wage studies?" Eastern Economic Review, 26, no. 3 (2000): 265-276.

Mrnjavac, Željko.Mjerenje nezaposlenosti. Split: Ekonomski fakultet Split, 1996.

Mrnjavac, Željko. "Povijest ekonomije rada i pogleda ekonomske teorije na nezaposlenost." In Uloga povijesti ekonomske misli u nastavi na fakultetima društvenih znanosti u Hrvatskoj, Druga znanstvena konferencija katedri za ekonomsku teoriju ekonomskih fakulteta $u$ 
Hrvatskoj, edited by Đuro Š. Medić and Ivan Ferenčak, 17-39. Osijek: Ekonomski fakultet, 2001.

Neumark, David and William L. Wascher.Minimum wages. United States: The MIT Press, 2008.

Sutch, Ritchard."The unexpected long-run impact of the minimum wage: an educational cascade", NBER Working Paper No. 16355 (2010): http://www.nber.org/papers/w16355.pdf

Vaughan Whitehead, Daniel. "Minimum wage revival in the enlarged EU: explanatory factors and developments". InThe minimum wage revisited in the enlarged EU, edited by Daniel Vaughan Whitehead, 1-56. International Labour Organization: Edward Elgar Publishing Limited, 2010.

Williams, Nicolas and Jeffrey A. Mills, J.A. "The minimum wage and teenage employment: evidence from time series,"Applied Economics, 33, no. 3 (2001): 285-300.

\section{APPENDIX}

TABLE A1

Method: analysis, OLS with fixed effects and robust standard errors of differenced variables Dependent variable: employment rate

Sample: 2001S2 2010 S2

Total number of observations (balanced panel): 140

\begin{tabular}{|c|c|c|c|c|}
\hline Variable* & Coefficient & St. error & t statistics & $p$ value \\
\hline $\bar{C}$ & -22.03247 & 11.26007 & -1.956690 & 0.0526 \\
\hline$X_{1}$ & 0.412184 & 0.059965 & 6.873726 & 0.0000 \\
\hline$X_{2}$ & 7.569952 & 3.272472 & 2.313222 & 0.0224 \\
\hline$X_{3}$ & -0.037202 & 0.037105 & -1.002620 & 0.3180 \\
\hline$X_{4}$ & -0.056281 & 0.220268 & -0.255511 & 0.7988 \\
\hline$X_{5}$ & 0.015105 & 0.016193 & 0.932820 & 0.3527 \\
\hline$X_{6}$ & 0.054134 & 0.014789 & 3.660355 & 0.0004 \\
\hline$X_{7}$ & -0.148818 & 0.061618 & -2.415168 & 0.0172 \\
\hline$X_{8}$ & 0.194912 & 0.043115 & 4.520773 & 0.0000 \\
\hline$X_{9}$ & 6.078202 & 1.519540 & 4.000028 & 0.0001 \\
\hline$X_{10}$ & -0.191422 & 0.386328 & -0.495490 & 0.6211 \\
\hline$R^{2}$ & \multicolumn{4}{|c|}{0.997817} \\
\hline Adjusted $R^{2}$ & \multicolumn{4}{|c|}{0.997533} \\
\hline DW statistics & & & 3398 & \\
\hline
\end{tabular}

Source: Research results

* List of independent variables: $X_{1}$ - lagged dependent variable; $X_{2}$ - differenced log of net minimum wage; $X_{3}$ - lag of GDP growth rate (differenced); $X_{4}$ - average working experience; $X_{5}$ share of urban population; $X_{6}$ - share of women; $X_{7}$ - share of highly educated workers; $X_{8}$ - share of covered workers; $X_{9}$ - log of average wage; $X_{10}$ - Minimum Wage Act implemented (dummy variable) 


\section{TABLE A2}

Method: analysis, OLS with fixed effects and robust standard errors of differenced variables Dependent variable: employment rate

Sample: 2001S2 2010S2

Total number of observations (balanced panel): 140

\begin{tabular}{|c|c|c|c|c|}
\hline Variable* & Coefficient & St. error & t statistics & $p$ value \\
\hline$\overline{C C}$ & -25.22809 & 11.76952 & -2.143511 & 0.0340 \\
\hline$X_{1}$ & 0.412258 & 0.061134 & 6.743468 & 0.0000 \\
\hline$x_{2}$ & 0.004772 & 0.064299 & 0.074214 & 0.9410 \\
\hline$x_{3}$ & -0.071195 & 0.049210 & -1.446749 & 0.1505 \\
\hline$X_{4}$ & -0.055909 & 0.224962 & -0.248527 & 0.8041 \\
\hline$X_{5}$ & 0.019058 & 0.015114 & 1.260948 & 0.2097 \\
\hline$X_{6}$ & 0.054803 & 0.014270 & 3.840395 & 0.0002 \\
\hline$X_{7}$ & -0.153326 & 0.065190 & -2.351992 & 0.0203 \\
\hline$X_{8}$ & 0.175053 & 0.047701 & 3.669815 & 0.0004 \\
\hline$X_{9}$ & 6.478848 & 1.600328 & 4.048449 & 0.0001 \\
\hline$X_{10}$ & -0.252169 & 0.455328 & -0.553819 & 0.5807 \\
\hline$R^{2}$ & \multicolumn{4}{|c|}{0.997776} \\
\hline Adjusted $R^{2}$ & \multicolumn{4}{|c|}{0.997487} \\
\hline DW statistics & \multicolumn{4}{|c|}{2.248449} \\
\hline
\end{tabular}

Source: Research results

* List of independent variables: $X_{1}$ - lagged dependent variable; $X_{2}$ - Kaitz index differenced (average wage); $X_{3}$ - lag of GDP growth rate (differenced); $X_{4}$ - average working experience; $X_{5}$ share of urban population; $X_{6}$ - share of women; $X_{7}$ - share of highly educated workers; $X_{8}$ - share ofcovered workers; $X_{9}$ - log of average wage; $X_{10}$ - Minimum Wage Act implemented (dummy variable) 


\section{TABLE A3}

Method: Panel analysis (workers 15-19 years), OLS with fixed effects and robust standard errors of differenced variables

Dependent variable: employment rate differenced

Sample: 2001S2 2010 S2

Total number of observations: 20

\begin{tabular}{|c|c|c|c|c|}
\hline Variable* & Coefficient & St. error & t statistics & $p$ value \\
\hline C & 2.373261 & 1.370615 & 1.731530 & 0.1140 \\
\hline$X_{1}$ & -0.626470 & 0.386757 & -1.619805 & 0.1363 \\
\hline$x_{2}$ & 12.01736 & 10.27443 & 1.169638 & 0.2693 \\
\hline$X_{3}$ & 0.133231 & 0.101631 & 1.310927 & 0.2192 \\
\hline$X_{4}$ & -0.006883 & 0.044060 & -0.156220 & 0.8790 \\
\hline$X_{5}$ & 0.022340 & 0.019807 & 1.127907 & 0.2857 \\
\hline$X_{6}$ & -6.170116 & 10.26444 & -0.601116 & 0.5611 \\
\hline$X_{7}$ & 0.138046 & 0.150963 & 0.914436 & 0.3820 \\
\hline$X_{8}$ & -6.654417 & 1.755037 & -3.791611 & 0.0035 \\
\hline$X_{9}$ & -0.842607 & 0.973632 & -0.865426 & 0.4071 \\
\hline $\mathrm{R}^{2}$ & \multicolumn{4}{|c|}{0.651356} \\
\hline Adjusted $R^{2}$ & \multirow{2}{*}{\multicolumn{4}{|c|}{$\begin{array}{l}0.337576 \\
1.651500\end{array}$}} \\
\hline DW statistics & & & & \\
\hline
\end{tabular}

Source: Research results

* List of independent variables: $X_{1}$ - lagged dependent variable (differenced); $X_{2}$ - differenced log of net minimum wage; $X_{3}$ - lag of GDP growth rate (differenced); $X_{4}$ - share of urban population; $X_{5}$ - share of women (differenced); $X_{6}$ - log of average wage (differenced); $X_{7}$ - share of covered workers; $X_{8}$ - working experience; $X_{9}$ - Minimum Wage Act implemented (dummy variable) 
TABLE A4

Method: Panel analysis (workers 15-19 years), OLS with fixed effects and robust standard errors of differenced variables

Dependent variable: employment rate differenced

Sample: 2001S2 2010 S2

Total number of observations: 20

\begin{tabular}{|c|c|c|c|c|}
\hline Variable* & Coefficient & St. error & t statistics & $p$ value \\
\hline$C$ & 2.448097 & 1.387642 & 1.764214 & 0.1082 \\
\hline$X_{1}$ & -0.623317 & 0.391088 & -1.593801 & 0.1421 \\
\hline$x_{2}$ & 0.153635 & 0.150354 & 1.021824 & 0.3309 \\
\hline$X_{3}$ & 0.130658 & 0.102963 & 1.268970 & 0.2332 \\
\hline$X_{4}$ & -0.006707 & 0.044083 & -0.152135 & 0.8821 \\
\hline$X_{5}$ & 0.022955 & 0.019897 & 1.153673 & 0.2755 \\
\hline$X_{6}$ & 4.642756 & 14.02087 & 0.331132 & 0.7474 \\
\hline$X_{7}$ & 0.133741 & 0.152216 & 0.878630 & 0.4002 \\
\hline$X_{8}$ & -6.698305 & 1.790152 & -3.741751 & 0.0038 \\
\hline$X_{9}$ & -0.845869 & 0.979930 & -0.863194 & 0.4083 \\
\hline $\mathrm{R}^{2}$ & \multicolumn{4}{|c|}{0.647737} \\
\hline Adjusted $R^{2}$ & \multicolumn{4}{|c|}{0.330700} \\
\hline DW statistics & \multicolumn{4}{|c|}{1.651216} \\
\hline
\end{tabular}

Source: Research results

* List of independent variables: $X_{1}$ - lagged dependent variable (differenced); $X_{2}$ - Kaitz index differenced (average wage); $X_{3}$ - lag of GDP growth rate (differenced); $X_{4}$ - share of urban population; $X_{5}$ - share of women (differenced); $X_{6}$ - log of average wage (differenced); $X_{7}$ - share ofcovered workers; $X_{8}$ - working experience; $X_{9}$ - Minimum Wage Act implemented (dummy variable) 


\section{TABLE A5}

Method: Panel analysis (workers 20-24 years), OLS with fixed effects and robust standard errors of differenced variables

Dependent variable: employment rate differenced

Sample: 2001S2 2010 S2

Total number of observations: 20

\begin{tabular}{|c|c|c|c|c|}
\hline Variable* & Coefficient & St. error & t statistics & $p$ value \\
\hline C & -23.47661 & 78.48593 & -0.299119 & 0.7716 \\
\hline$X_{1}$ & -0.592093 & 0.392759 & -1.507520 & 0.1659 \\
\hline$X_{2}$ & 21.22722 & 33.46742 & 0.634265 & 0.5417 \\
\hline$x_{3}$ & -0.242997 & 0.227182 & -1.069615 & 0.3126 \\
\hline$X_{4}$ & 0.117656 & 0.190652 & 0.617125 & 0.5524 \\
\hline$X_{5}$ & 0.025213 & 0.465781 & 0.054132 & 0.9580 \\
\hline$X_{6}$ & 1.298108 & 1.104434 & 1.175361 & 0.2700 \\
\hline$X_{7}$ & 2.305588 & 10.40176 & 0.221654 & 0.8295 \\
\hline$X_{8}$ & 0.331464 & 0.991718 & 0.334232 & 0.7459 \\
\hline$X_{9}$ & 0.655289 & 5.450495 & 0.120226 & 0.9069 \\
\hline$X_{10}$ & -4.360007 & 2.317687 & -1.881189 & 0.0926 \\
\hline $\mathrm{R}^{2}$ & \multicolumn{4}{|c|}{0.643422} \\
\hline Adjusted R² & \multicolumn{4}{|c|}{0.247225} \\
\hline DW statistics & \multicolumn{4}{|c|}{2.765581} \\
\hline
\end{tabular}

Source: Research results

* List of independent variables: $X_{1}$ - lagged dependent variable (differenced); $\mathbf{X}_{2}$ - differenced log of net minimum wage; $X_{3}$ - lag of GDP growth rate (differenced); $X_{4}$ - share of urban population (differenced); $X_{5}$ - share of women (differenced); $X_{6}$ - share of highly educated workers; $X_{7}-\log$ of average wage; $X_{8}$ - share ofcovered workers; $X_{9}$ - working experience; $X_{10}$ - Minimum Wage Act implemented (dummy variable) 


\section{TABLE A6}

Method: Panel analysis (workers 20-24 years), OLS with fixed effects and robust standard errors of differenced variables

Dependent variable: employment rate differenced

Sample: 2001S2 2010 S2

Total number of observations: 20

\begin{tabular}{|c|c|c|c|c|}
\hline Variable* & Coefficient & St. error & t statistics & $\mathrm{p}$ value \\
\hline C & -6.664144 & 83.56070 & -0.079752 & 0.9382 \\
\hline$X_{1}$ & -0.516600 & 0.307821 & -1.678248 & 0.1276 \\
\hline$X_{2}$ & 0.189170 & 0.488323 & 0.387386 & 0.7075 \\
\hline$X_{3}$ & -0.258838 & 0.227396 & -1.138268 & 0.2844 \\
\hline$X_{4}$ & 0.127942 & 0.184818 & 0.692258 & 0.5062 \\
\hline$X_{5}$ & 0.074846 & 0.523280 & 0.143032 & 0.8894 \\
\hline$X_{6}$ & 1.444969 & 1.093380 & 1.321561 & 0.2189 \\
\hline$X_{7}$ & -0.274378 & 10.72893 & -0.025574 & 0.9802 \\
\hline$X_{8}$ & 0.581173 & 0.815662 & 0.712517 & 0.4942 \\
\hline$X_{9}$ & 2.051541 & 5.802630 & 0.353554 & 0.7318 \\
\hline$X_{10}$ & -4.041006 & 2.446338 & -1.651860 & 0.1330 \\
\hline$R^{2}$ & \multicolumn{4}{|c|}{0.637043} \\
\hline Adjusted $R^{2}$ & \multicolumn{4}{|c|}{0.233757} \\
\hline DW statistics & \multicolumn{4}{|c|}{2.746658} \\
\hline
\end{tabular}

Source: Research results

${ }^{*}$ List of independent variables: $X_{1}$ - lagged dependent variable (differenced); $X_{2}$ - Kaitz index differenced (average wage); $X_{3}$ - lag of GDP growth rate (differenced); $X_{4}$ - share of urban population (differenced); $X_{5}$ - share of women (differenced); $X_{6}$ - share of highly educated workers; $\mathrm{X}_{7}$ - $\log$ of average wage; $\mathrm{X}_{8}$ - share ofcovered workers; $\mathrm{X}_{9}$ - working experience; $\mathrm{X}_{10}$ - Minimum Wage Act implemented (dummy variable) 


\section{TABLE A7}

Method: Panel analysis (workers 25-29 years), OLS with fixed effects and robust standard errors of differenced variables

Dependent variable: employment rate differenced

Sample: 2001S2 2010 S2

Total number of observations: 20

\begin{tabular}{|c|c|c|c|c|}
\hline Variable* & Coefficient & St. error & t statistics & $p$ value \\
\hline$\overline{C \mathrm{C}}$ & -16.27036 & 20.17768 & -0.806354 & 0.4388 \\
\hline$X_{1}$ & -0.820289 & 0.229606 & -3.572593 & 0.0051 \\
\hline$X_{2}$ & 34.39641 & 21.59008 & 1.593158 & 0.1422 \\
\hline$x_{3}$ & -0.246824 & 0.083577 & -2.953237 & 0.0145 \\
\hline$X_{4}$ & -0.101695 & 0.224200 & -0.453590 & 0.6598 \\
\hline$x_{5}$ & 0.299755 & 0.415193 & 0.721965 & 0.4869 \\
\hline$X_{6}$ & -0.099214 & 0.339190 & -0.292503 & 0.7759 \\
\hline$x_{7}$ & 51.41328 & 29.34406 & 1.752085 & 0.1103 \\
\hline$X_{8}$ & 1.102969 & 0.676534 & 1.630324 & 0.1341 \\
\hline$X_{9}$ & -6.966908 & 2.368978 & -2.940892 & 0.0148 \\
\hline $\mathrm{R}^{2}$ & \multicolumn{4}{|c|}{0.654931} \\
\hline Adjusted $R^{2}$ & \multicolumn{4}{|c|}{0.344369} \\
\hline DW statistics & \multicolumn{4}{|c|}{2.092116} \\
\hline
\end{tabular}

Source: Research results

* List of independent variables: $X_{1}$ - lagged dependent variable (differenced); $X_{2}$ - differenced log of net minimum wage; $X_{3}$ - lag of GDP growth rate (differenced); $X_{4}$ - share of urban population (differenced); $X_{5}$ - share of women; $X_{6}$ - share of highly educated workers (differenced); $X_{7}-\log$ of average wage (differenced); $X_{8}$ - share ofcovered workers; $X_{9}$ - Minimum Wage Act implemented (dummy variable) 
TABLE A8

Method: Panel analysis (workers 25-29 years), OLS with fixed effects and robust standard errors of differenced variables

Dependent variable: employment rate differenced

Sample: 2001S2 2010 S2

Total number of observations: 20

\begin{tabular}{|c|c|c|c|c|}
\hline Variable* & Coefficient & St. error & t statistics & $p$ value \\
\hline$\overline{C \mathrm{C}}$ & -16.28188 & 19.81275 & -0.821788 & 0.4304 \\
\hline$X_{1}$ & -0.830678 & 0.221473 & -3.750695 & 0.0038 \\
\hline$x_{2}$ & 0.708678 & 0.389509 & 1.819414 & 0.0989 \\
\hline$x_{3}$ & -0.231552 & 0.076501 & -3.026770 & 0.0127 \\
\hline$X_{4}$ & -0.093205 & 0.219206 & -0.425193 & 0.6797 \\
\hline$X_{5}$ & 0.299348 & 0.407987 & 0.733718 & 0.4800 \\
\hline$x_{6}$ & -0.095655 & 0.341570 & -0.280045 & 0.7852 \\
\hline$X_{7}$ & 86.98043 & 38.08712 & 2.283723 & 0.0455 \\
\hline$X_{8}$ & 1.105464 & 0.666724 & 1.658053 & 0.1283 \\
\hline$X_{9}$ & -7.017532 & 2.220065 & -3.160959 & 0.0101 \\
\hline$R^{2}$ & \multicolumn{4}{|c|}{0.667228} \\
\hline Adjusted $R^{2}$ & \multirow{2}{*}{\multicolumn{4}{|c|}{$\begin{array}{l}0.367734 \\
2.091443\end{array}$}} \\
\hline DW statistics & & & & \\
\hline
\end{tabular}

Source: Research results

* List of independent variables: $X_{1}$ - lagged dependent variable (differenced); $X_{2}$ - Kaitz index differenced (average wage); $X_{3}$ - lag of GDP growth rate (differenced); $X_{4}$ - share of urban population (differenced); $X_{5}$ - share of women; $X_{6}$ - share of highly educated workers (differenced); $X_{7}-\log$ of average wage (differenced); $X_{8}$ - share ofcovered workers; $X_{9}$ - Minimum Wage Act implemented (dummy variable) 


\section{TABLE A9}

Method: Panel analysis (workers 30-39 years), OLS with fixed effects and robust standard errors of differenced variables

Dependent variable: employment rate differenced

Sample: 2001S2 2010 S2

Total number of observations: 20

\begin{tabular}{|c|c|c|c|c|}
\hline Variable* & Coefficient & St. error & t statistics & $\mathrm{p}$ value \\
\hline $\bar{C}$ & -75.36184 & 42.75637 & -1.762587 & 0.1118 \\
\hline$X_{1}$ & -1.012716 & 0.400198 & -2.530538 & 0.0322 \\
\hline$X_{2}$ & 13.47561 & 12.29516 & 1.096009 & 0.3015 \\
\hline$X_{3}$ & 0.033644 & 0.213723 & 0.157418 & 0.8784 \\
\hline$X_{4}$ & -0.236226 & 0.211859 & -1.115016 & 0.2937 \\
\hline$X_{5}$ & 0.502940 & 0.327582 & 1.535311 & 0.1591 \\
\hline$X_{6}$ & -0.165668 & 0.328459 & -0.504378 & 0.6261 \\
\hline$X_{7}$ & 0.686581 & 0.932470 & 0.736304 & 0.4803 \\
\hline$X_{8}$ & 6.651602 & 4.496173 & 1.479392 & 0.1732 \\
\hline$X_{9}$ & -0.632000 & 0.747100 & -0.845938 & 0.4195 \\
\hline$X_{10}$ & -4.701989 & 1.915455 & -2.454764 & 0.0365 \\
\hline$R^{2}$ & \multicolumn{4}{|c|}{0.598234} \\
\hline Adjusted R² & \multicolumn{4}{|c|}{0.151828} \\
\hline DW statistics & & & & \\
\hline
\end{tabular}

Source: Research results

* List of independent variables: $X_{1}$ - lagged dependent variable (differenced); $X_{2}$ - differenced log of net minimum wage; $X_{3}$ - lag of GDP growth rate (differenced); $X_{4}$ - share of urban population (differenced); $X_{5}$ - share of women; $X_{6}$ - share of highly educated workers; $X_{7}$ - average working experience (differenced); $X_{8}$ - log of average wage; $X_{9}$ - share of covered workers (differenced); $X_{10}$ Minimum Wage Act implemented (dummy variable) 
TABLE A10

Method: Panel analysis (workers 30-39 years), OLS with fixed effects and robust standard errors of differenced variables

Dependent variable: employment rate differenced

Sample: 2001S2 2010 S2

Total number of observations: 20

\begin{tabular}{|c|c|c|c|c|}
\hline Variable* & Coefficient & St. error & t statistics & $p$ value \\
\hline $\bar{C}$ & -63.35139 & 33.94350 & -1.866378 & 0.0948 \\
\hline$X_{1}$ & -0.834468 & 0.342918 & -2.433436 & 0.0378 \\
\hline$X_{2}$ & -0.145858 & 0.251477 & -0.580005 & 0.5761 \\
\hline$x_{3}$ & -0.033461 & 0.175381 & -0.190790 & 0.8529 \\
\hline$X_{4}$ & -0.157010 & 0.186300 & -0.842779 & 0.4212 \\
\hline$x_{5}$ & 0.215524 & 0.253523 & 0.850117 & 0.4173 \\
\hline$X_{6}$ & -0.426783 & 0.354930 & -1.202441 & 0.2599 \\
\hline$X_{7}$ & 0.425293 & 1.028895 & 0.413349 & 0.6890 \\
\hline$X_{8}$ & 7.226127 & 3.362048 & 2.149323 & 0.0601 \\
\hline$X_{9}$ & -0.474827 & 0.701662 & -0.676717 & 0.5156 \\
\hline$X_{10}$ & -3.586057 & 2.068450 & -1.733693 & 0.1170 \\
\hline$R^{2}$ & \multicolumn{4}{|c|}{0.584896} \\
\hline Adjusted $R^{2}$ & \multicolumn{4}{|c|}{0.123670} \\
\hline DW statistics & \multicolumn{4}{|c|}{2.425051} \\
\hline
\end{tabular}

Source: Research results

* List of independent variables: $X_{1}$ - lagged dependent variable (differenced); $X_{2}$ - Kaitz index differenced (average wage); $X_{3}$ - lag of GDP growth rate (differenced); $X_{4}$ - share of urban population (differenced); $X_{5}$ - share of women; $X_{6}$ - share of highly educated workers; $X_{7}$ - average working experience (differenced); $X_{8}$ - log of average wage; $X_{8}$ - share of covered workers (differenced); $X_{9}$ - Minimum Wage Act implemented (dummy variable) 


\section{TABLE A11}

Method: Panel analysis (workers 40-49 years), OLS with fixed effects and robust standard errors of differenced variables

Dependent variable: employment rate differenced

Sample: 2001S2 2010 S2

Total number of observations: 20

\begin{tabular}{|c|c|c|c|c|}
\hline Variable* & Coefficient & St. error & t statistics & $p$ value \\
\hline $\bar{C}$ & 71.66903 & 38.42618 & 1.865109 & 0.0950 \\
\hline$X_{1}$ & -0.486795 & 0.294706 & -1.651802 & 0.1330 \\
\hline$X_{2}$ & 5.450257 & 9.218466 & 0.591233 & 0.5689 \\
\hline$x_{3}$ & 0.008445 & 0.093152 & 0.090655 & 0.9298 \\
\hline$X_{4}$ & -0.215902 & 0.225568 & -0.957146 & 0.3635 \\
\hline$x_{5}$ & 0.079014 & 0.313464 & 0.252066 & 0.8067 \\
\hline$X_{6}$ & -0.784239 & 0.445586 & -1.760016 & 0.1123 \\
\hline$X_{7}$ & -0.656176 & 1.005258 & -0.652744 & 0.5302 \\
\hline$X_{8}$ & -6.353790 & 3.720450 & -1.707801 & 0.1219 \\
\hline$X_{9}$ & -0.094067 & 0.537526 & -0.174999 & 0.8650 \\
\hline$X_{10}$ & 0.238883 & 1.370316 & 0.174327 & 0.8655 \\
\hline$R^{2}$ & \multicolumn{4}{|c|}{0.519715} \\
\hline Adjusted $R^{2}$ & \multicolumn{4}{|c|}{-0.013935} \\
\hline DW statistics & \multicolumn{4}{|c|}{2.867885} \\
\hline
\end{tabular}

Source: Research results

* List of independent variables: $X_{1}$ - lagged dependent variable (differenced); $X_{2}$ - differenced log of net minimum wage; $X_{3}$ - lag of GDP growth rate (differenced); $X_{4}$ - share of urban population (differenced); $X_{5}$ - share of women; $X_{6}$ - share of highly educated workers; $X_{7}$ - average working experience; $X_{8}$ - log of average wage; $X_{9}$ - share ofcovered workers; $X_{10}$ - Minimum Wage Act implemented (dummy variable) 
TABLE A12

Method: Panel analysis (workers 40-49 years), OLS with fixed effects and robust standard errors of differenced variables

Dependent variable: employment rate differenced

Sample: 2001S2 2010S2

Total number of observations: 20

\begin{tabular}{|c|c|c|c|c|}
\hline Variable* & Coefficient & St. error & t statistics & $\mathrm{p}$ value \\
\hline C & 62.02009 & 30.48760 & 2.034273 & 0.0724 \\
\hline$X_{1}$ & -0.349883 & 0.282792 & -1.237245 & 0.2473 \\
\hline$X_{2}$ & 0.279464 & 0.258929 & 1.079305 & 0.3085 \\
\hline$X_{3}$ & 0.000989 & 0.082020 & 0.012061 & 0.9906 \\
\hline$X_{4}$ & -0.218114 & 0.214765 & -1.015594 & 0.3363 \\
\hline$X_{5}$ & 0.133940 & 0.259873 & 0.515404 & 0.6187 \\
\hline$X_{6}$ & -0.501901 & 0.466777 & -1.075247 & 0.3102 \\
\hline$X_{7}$ & -0.657353 & 0.808947 & -0.812604 & 0.4374 \\
\hline$X_{8}$ & -5.889457 & 3.590179 & -1.640435 & 0.1353 \\
\hline$X_{9}$ & 0.065591 & 0.393052 & 0.166875 & 0.8712 \\
\hline$X_{10}$ & -0.234516 & 1.421134 & -0.165020 & 0.8726 \\
\hline $\mathrm{R}^{2}$ & \multicolumn{4}{|c|}{0.594407} \\
\hline Adjusted R² & \multicolumn{4}{|c|}{0.143748} \\
\hline DW statistics & \multicolumn{4}{|c|}{2.731176} \\
\hline
\end{tabular}

Source: Research results

* List of independent variables: $X_{1}$ - lagged dependent variable (differenced): $X_{2}$ - Kaitz index differenced (average wage); $X_{3}$ - lag of GDP growth rate (differenced); $X_{4}$ - share of urban population (differenced); $X_{5}$ - share of women; $X_{6}$ - share of highly educated workers; $X_{7}$ - average working experience; $X_{8}$ - log of average wage; $X_{9}$ - share ofcovered workers; $X_{10}$ - Minimum Wage Act implemented (dummy variable) 
TABLE A13

Method: Panel analysis (workers 50-59 years), OLS with fixed effects and robust standard errors of differenced variables

Dependent variable: employment rate differenced

Sample: 2001S2 2010 S2

Total number of observations: 20

\begin{tabular}{|c|c|c|c|c|}
\hline Variable* & Coefficient & St. error & t statistics & $p$ value \\
\hline $\bar{C}$ & 1.081639 & 2.214482 & 0.488439 & 0.6369 \\
\hline$X_{1}$ & -0.428642 & 0.211975 & -2.022135 & 0.0739 \\
\hline$x_{2}$ & 3.459247 & 8.543145 & 0.404915 & 0.6950 \\
\hline$x_{3}$ & -0.134307 & 0.231677 & -0.579717 & 0.5763 \\
\hline$X_{4}$ & 0.240030 & 0.140937 & 1.703102 & 0.1228 \\
\hline$x_{5}$ & 0.375831 & 0.182759 & 2.056426 & 0.0699 \\
\hline$X_{6}$ & 0.135523 & 0.473767 & 0.286055 & 0.7813 \\
\hline$X_{7}$ & -0.273283 & 0.995338 & -0.274563 & 0.7899 \\
\hline$X_{8}$ & 16.23206 & 21.77753 & 0.745358 & 0.4751 \\
\hline$X_{9}$ & -0.329419 & 1.019019 & -0.323270 & 0.7539 \\
\hline$X_{10}$ & -1.018175 & 0.557972 & -1.824778 & 0.1013 \\
\hline$R^{2}$ & \multicolumn{4}{|c|}{0.621792} \\
\hline Adjusted R² & \multicolumn{4}{|c|}{0.201561} \\
\hline DW statistics & \multicolumn{4}{|c|}{2.299028} \\
\hline
\end{tabular}

Source: Research results

* List of independent variables: $X_{1}$ - lagged dependent variable (differenced); $X_{2}$ - differenced log of net minimum wage; $X_{3}$ - lag of GDP growth rate (differenced); $X_{4}$ - share of urban population (differenced); $X_{5}$ - share of women (differenced); $X_{6}$ - share of highly educated workers (differenced); $X_{7}$ - average working experience (differenced); $X_{8}$ - log of average wage (differenced); $X_{9}$ - share ofcovered workers; $X_{10}$ - Minimum Wage Act implemented (dummy variable) 
TABLE A14

Method: Panel analysis (workers 50-59 years), OLS with fixed effects and robust standard errors of differenced variables

Dependent variable: employment rate differenced

Sample: 2001S2 2010 S2

Total number of observations: 20

\begin{tabular}{|c|c|c|c|c|}
\hline Variable* & Coefficient & St. error & t statistics & $p$ value \\
\hline $\bar{C}$ & 1.104365 & 2.205457 & 0.500742 & 0.6286 \\
\hline$X_{1}$ & -0.432577 & 0.215734 & -2.005140 & 0.0759 \\
\hline$x_{2}$ & 0.065594 & 0.188021 & 0.348866 & 0.7352 \\
\hline$x_{3}$ & -0.135873 & 0.242365 & -0.560612 & 0.5887 \\
\hline$X_{4}$ & 0.239460 & 0.143910 & 1.663950 & 0.1305 \\
\hline$x_{5}$ & 0.377322 & 0.182307 & 2.069708 & 0.0684 \\
\hline$x_{6}$ & 0.134662 & 0.489346 & 0.275187 & 0.7894 \\
\hline$x_{7}$ & -0.287135 & 0.991844 & -0.289496 & 0.7788 \\
\hline$X_{8}$ & 18.91819 & 22.81649 & 0.829146 & 0.4285 \\
\hline$x_{9}$ & -0.330839 & 1.043133 & -0.317159 & 0.7584 \\
\hline$X_{10}$ & -1.022830 & 0.558840 & -1.830273 & 0.1005 \\
\hline $\mathrm{R}^{2}$ & \multicolumn{4}{|c|}{0.621242} \\
\hline Adjusted $R^{2}$ & \multicolumn{4}{|c|}{0.200399} \\
\hline DW statistics & \multicolumn{4}{|c|}{2.302043} \\
\hline
\end{tabular}

Source: Research results

* List of independent variables: $X_{1}$ - lagged dependent variable (differenced); $X_{2}$ - Kaitz index differenced (average wage); $X_{3}$ - lag of GDP growth rate (differenced); $X_{4}$ - share of urban population (differenced); $X_{5}$ - share of women (differenced); $X_{6}$ - share of highly educated workers (differenced); $X_{7}$ - average working experience (differenced); $X_{8}$ - log of average wage (differenced); $X_{9}$ - share ofcovered workers; $X_{10}$ - Minimum Wage Act implemented (dummy variable) 
TABLE A15

Method: Panel analysis (workers 60-65 years), OLS with fixed effects and robust standard errors of differenced variables

Dependent variable: employment rate differenced

Sample: 2001S2 2010 S2

Total number of observations: 20

\begin{tabular}{|c|c|c|c|c|}
\hline Variable* & Coefficient & St. error & t statistics & $p$ value \\
\hline$C$ & 76.08386 & 26.18024 & 2.906156 & 0.0174 \\
\hline$X_{1}$ & -0.988193 & 0.147761 & -6.687766 & 0.0001 \\
\hline$x_{2}$ & 27.30380 & 11.63833 & 2.346025 & 0.0436 \\
\hline$X_{3}$ & -0.130079 & 0.045392 & -2.865708 & 0.0186 \\
\hline$X_{4}$ & 0.020526 & 0.087377 & 0.234917 & 0.8195 \\
\hline$X_{5}$ & -0.080252 & 0.054698 & -1.467169 & 0.1764 \\
\hline$X_{6}$ & -0.036567 & 0.070218 & -0.520769 & 0.6151 \\
\hline$X_{7}$ & -1.202431 & 0.408085 & -2.946517 & 0.0163 \\
\hline$X_{8}$ & -8.897870 & 3.011115 & -2.955009 & 0.0161 \\
\hline$X_{9}$ & -0.588473 & 0.352989 & -1.667113 & 0.1298 \\
\hline$X_{10}$ & 0.838523 & 0.537559 & 1.559872 & 0.1532 \\
\hline$R^{2}$ & \multicolumn{4}{|c|}{0.725113} \\
\hline Adjusted $R^{2}$ & \multicolumn{4}{|c|}{0.419682} \\
\hline DW statistics & \multicolumn{4}{|c|}{2.092681} \\
\hline
\end{tabular}

Source: Research results

* List of independent variables: $X_{1}$ - lagged dependent variable (differenced); $X_{2}$ - differenced log of net minimum wage; $X_{3}$ - lag of GDP growth rate (differenced); $X_{4}$ - share of urban population; $X_{5}$ - share of women (differenced); $X_{6}$ - share of highly educated workers; $X_{7}$ - average working experience (differenced); $X_{8}$ - log of average wage; $X_{9}$ - share ofcovered workers; $X_{10}$ - Minimum Wage Act implemented (dummy variable) 
TABLE A16

Method: Panel analysis (workers 60-65 years), OLS with fixed effects and robust standard errors of differenced variables

Dependent variable: employment rate differenced

Sample: 2001S2 2010 S2

Total number of observations: 20

\begin{tabular}{lcccc}
\hline \hline Variable* & Coefficient & St. error & t statistics & p value \\
\hline \hline$C$ & & & & \\
$X_{1}$ & 25.71710 & 24.32563 & 1.057202 & 0.3180 \\
$X_{2}$ & -0.796427 & 0.221145 & -3.601386 & 0.0057 \\
$X_{3}$ & 0.036511 & 0.197008 & 0.185325 & 0.8571 \\
$X_{4}$ & -0.159796 & 0.054494 & -2.932333 & 0.0167 \\
$X_{5}$ & -0.022015 & 0.095051 & -0.231617 & 0.8220 \\
$X_{6}$ & -0.082491 & 0.059524 & -1.385827 & 0.1992 \\
$X_{7}$ & 0.064192 & 0.079343 & 0.809045 & 0.4394 \\
$X_{8}$ & -0.431273 & 0.228280 & -1.889227 & 0.0914 \\
$X_{9}$ & -2.982084 & 2.822612 & -1.056498 & 0.3183 \\
$X_{10}$ & -0.116322 & 0.356796 & -0.326017 & 0.7519 \\
$R^{2}$ & 0.857277 & 0.508563 & 1.685684 & 0.1261 \\
Adjusted R ${ }^{2}$ & & 0.596600 & \\
DW statistics & & 0.148378 & & \\
\hline \hline
\end{tabular}

Source: Research results

* List of independent variables: $X_{1}$ - lagged dependent variable (differenced); $X_{2}$ - Kaitz index differenced (average wage); $X_{3}$ - lag of GDP growth rate (differenced); $X_{4}$ - share of urban population; $X_{5}$ - share of women (differenced); $X_{6}$ - share of highly educated workers; $X_{7}$ - average working experience (differenced); $X_{8}$ - log of average wage; $X_{9}$ - share ofcovered workers; $X_{10}$ Minimum Wage Act implemented (dummy variable) 


\section{SMANJUJE LI SE ZAPOSLENOST USLIJED POVEĆANJA MINIMALNE PLAĆE?}

Sažetak: Svrha ovoga rada je modelirati i kvantificirati vezu između minimalne plaće i stope zaposlenosti radnika distribuiranih po dobi u Republici Hrvatskoj primjenom podataka iz Ankete o radnoj snazi za period od 2000. do 2010. years i korištenjem panel metode s fiksnim efektima s ciljem dokazivanja pretpostavljene hipoteze o negativnome utjecaju povećanja minimalne plaće na stopu zaposlenosti ugroženih skupina radnika. Rezultati istraživanja ukazuju na postojanje veze pozitivnog smjera no s malom praktičnom značajnošću s obzirom da su potrebna osjetna povećanja visine minimalne plaće.

Ključne riječi: minimalna plaća, stopa zaposlenosti, Kaitz indeks, Hrvatska 